\title{
ANALÝZA BETA-KONVERGENCE REGIONŮ ZEMÍ VISEGRÁDSKÉ ČTYŘKY PROSTŘEDNICTVÍM NELINEÁRNÍHO REGRESNÍHO MODELU ${ }^{1}$
}

\author{
Jan Nevima, Lukáš Melecký
}

\section{Klíčová slova:}

reálná konvergence, region, NUTS 2, Visegrádská čtyřka, beta konvergence, empirická analýza, regresní ekonometrický model

\section{Key words:}

real convergence, region, NUTS 2, Visegrad Four, beta convergence, empirical analysis, regression econometric model,

\begin{abstract}
Abstrakt
Článek zkoumá a analyzuje proces reálné konvergence v zemích Visegrádské čtyřky na úrovni regionů NUTS 2. Teoretická východiska př́spěvku vymezují metodologický koncept a definici konvergence se zaměřením na pojetí beta konvergence, jež je př́padem nepodmíněné (absolutní) konvergence, a tento přístup je založen na neoklasickém modelu růstu. Empirická část příspěvku je zaměřena na analýzu beta konvergence regionů NUTS 2 zemí Visegrádské čtyřky v referenčním období 1995 - 2006. Beta konvergence je analyzována prostřednictvím nelineárního regresního ekonometrického modelu, jenž je formulován ve dvou variacích vycházejících $\mathrm{z}$ matematického konceptu deterministické konvergence. Pro odhad obou modelů byl použit ukazatel hrubého domácího produktu na obyvatele ve stálých cenách.
\end{abstract}

\begin{abstract}
The paper examines and analyzes the process of real convergence in the Visegrad countries at regional level NUTS 2. Theoretical background of the paper defines the methodological concept and definition of convergence, focusing on the concept of beta convergence, which is the case of unconditional (absolute) convergence. This approach is based on the neoclassical growth model. The empirical part of the article focuses on the analysis of beta convergence in NUTS 2 regions of the Visegrad Four countries in the reference period 1995 - 2006. Beta convergence is analyzed by nonlinear regression econometric model, which is formulated in two variations based on the mathematical concept of deterministic convergence. To estimate both models, indicator of gross domestic product per capita in constant prices was used.
\end{abstract}

\section{Úvod}

Fenomén konvergence představuje v podmínkách EU, ale nejen tam, jeden ze základních ekonomických předpokladů pro posílení konkurenceschopnosti a soudržnosti v rozšrirrené Evropské unii. Termín konvergence, obdobně jako konkurenceschopnost či soudržnost, má své teoretické zázemí, definici, přístupy a možnosti měření. Metodologické vymezení konvergence je předmětem první kapitoly. Příspěvek je tematicky zaměřen na problematiku konvergence reálné, která je testována na regionální úrovni, což je přístup menšinový a do

\footnotetext{
${ }^{1}$ Př́íspěvek vznikl v rámci řešení projektu GAČR Makroekonomické modely české ekonomiky a dalších zemí EU. Registrační číslo projektu: 402/08/1015.
} 
jisté míry nevšední, nebot' v širokém spektru prací věnovaných analýze reálné konvergence převažuje, zejména $v$ českých podmínkách, hledisko národní, jak ukazují např. studie (Frait, Komárek, 2001), (Žd'árek, 2006), (Slavík, 2005, 2007), (Smrčková, Vlček, Cvengroš, 2008) či (Dvoroková, 2009). I v domácí literatuře však můžeme nalézt práce věnované analýze regionální konvergence jako např. (Hančlová, 2010), (Melecký, L., 2010), (Melecký, Nevima, 2010a, 2010b). V zahraniční literatuře pak převažují práce zaměřené na rozměr mimo EU či pouze v rámci zemí EU15, jako jsou napřr. studie (Sala-i-Martin, 1996), (Magrini, 2004), (Kutan, Yigit, 2007), (Ramajo, Márquez, Hewings, Salinas, 2008), (Romeo-Avila, 2009) a další.

Cílem vědeckého článku je v teoretické rovině přiblížit metodologická východiska konceptu konvergence a následně v praktické rovině analyzovat a ověřit platnost procesu reálné konvergence $\mathrm{v}$ regionech zemí Visegrádské čtyřky (V4) na základě přístupu beta $(\beta)$ konvergence. Budeme se tedy snažit odpovědět na otázku, zda vývoj ekonomické úrovně v regionech NUTS 2 Visegrádské čtyřky je v souladu s teoretickými předpoklady konceptu $\beta$-konvergence, jež platí na úrovni států, či nikoliv. Celkem budou představeny dva matematické př́stupy, jež vyúst'ují do formulace dvou odvozených nelineárních regresních ekonometrických modelů, jež je možné vnímat jako určité alternativy k tradičním postupům.

Metodologická východiska článku souvisí s několika základními aspekty, které ovlivňují odhad modelu, a tudíž i samotné výsledky hodnocení regionální konvergence. Jedná se především o (1) výběr zvolené územní úrovně regionu, (2) délku posuzovaného období, (3) periodicitu dat, (4) výběr vhodných ukazatelů pro analýzu na základě dostupných regionálních dat a (5) volbu tzv. stálého stavu. Základním nedostatkem, na který při zkoumání regionálních dat narážíme, jsou krátké časové řady regionálních ekonomických dat. Pro potřeby hodnocení regionální konvergence $\mathrm{v}$ podmínkách EU se jako nejvhodnější územní jednotka, v rámci nomenklatury územních statistických jednotek, jeví úroveň NUTS 2, která je předmětem zájmu Evropské komise z hlediska naplňování cílů politiky hospodářské a sociální soudržnosti EU. V analytické části př́spěvku hodnotíme reálnou konvergenci 35 regionů České republiky, Polska, Slovenska a Mad'arska prostřednictvím nelineárního regresního ekonometrického modelu pro testování $\beta$-konvergence. Koncept $\beta$-konvergence definuje potřebu vymezení stálého stavu. Pro účely tohoto příspěvku je stálým stavem průměrná ekonomická úroveň zemí EU15. Volba stálého stavu v podobě ekonomické úrovně EU15 byla stanovena záměrně, nebot' v empirické části příspěvku je testována konvergence regionů zemí Visegrádské čtyřky k zemím EU15, které jsou ve většině případů ekonomicky vyspělejší.

\section{Definice a pojetí konvergence}

\subsection{Definice konvergence}

Vymezení pojmu konvergence je z pohledu ekonomických teorií poměrně složitým problémem, nebot' je tento pojem používán v různých modifikacích závislých na typu zkoumaného problému. Podíváme-li se na definici pojmu konvergence jako takové, tak konvergence intuitivně znamená, že se rozdíl mezi dvěma či více veličinami v čase snižuje a stává se zanedbatelným, respektive konverguje k nule. Konvergence je tedy chápána jako proces, který představuje přibližování se určité úrovni, resp. snižování rozdílu mezi dvěma veličinami $\mathrm{v}$ čase ( $\mathrm{tj}$. diference obou proměnných se $\mathrm{v}$ čase zmenšuje směrem $\mathrm{k}$ nulové hodnotě). V ekonomické literatuře se obvykle setkáváme se dvěma základními typy konvergence - reálnou a nominální. Chápání těchto koncepcí není mezi jednotlivými autory jednoznačné a je tudíž vhodné věnovat mu bližší pozornost. 
Reálná konvergence představuje přibližování ekonomické úrovně země k úrovni jiné vyspělé země nebo skupiny zemí (v rámci integračního seskupení). Zpravidla se měří pomocí ukazatele HDP na obyvatele (HDP per capita), který vylučuje vliv cenových úrovní a představuje skutečnou výši produkovaného zboží a služeb danou ekonomikou. Mezinárodní srovnání se provádí přepočtem podle parity kupní síly (PPP) nebo parity kupního standardu (PPS). Reálnou konvergenci lze také chápat jako strukturální sbližování ekonomik nebo používaných technologií, jak uvádí např. (Slavík, 2005). Pokud hodnotíme vztah ekonomické úrovně mezi dvěma ekonomickými celky, můžeme definici konvergence ekonomické veličiny (HDP na obyvatele) dvou zemí (regionů) v čase $t$ vyjádřit na základě absolutní hodnoty diference jako např. (Slavík, 2007, s. 24) nebo (Dvoroková, 2009, s. 3). Formalizovaný zápis definice konvergence v období $t$ a $t+1$ pak má následující podobu:

$$
\left|y_{1, t}-y_{2, t}\right|>\left|y_{1, t+1}-y_{2, t+1}\right|
$$

kde $y_{1, t}$ a $y_{2, t}$ jsou relevantní ekonomické veličiny dvou zemí v čase $t$. Případ s opačným znaménkem pak nazýváme divergencí. Jde o situaci, kdy se země z hlediska ekonomické vyspělosti od sebe vzdalují. Objevují se však i jiné formalizované zápisy pro hodnocení konvergence jako např. formou relativních odstupi̊, viz např. (Smrčková, Vlček, Cvengroš, 2008, s. 1). Formalizovaný zápis lze vyjádřit takto:

$$
\frac{y_{1, t}}{y_{2, t}}<\frac{y_{1, t+1}}{y_{2, t+1}} \text { pro } y_{1, t}<y_{2, t}
$$

kde $y$ je reálný důchod na osobu celku 1 a 2 v čase $t$ a $t+1$. Tento vztah lze interpretovat tak, že relativní odstup ekonomických úrovní na obyvatele se v čase $t$ snižuje.

$\mathrm{V}$ případě reálné konvergence, často také označované jako koncept absolutní (nepodmíněné) konvergence, např. (Žd’árek, 2006), (Slavík, 2005), je teoretickou fundací neoklasická teorie růstu, která předpokládá přibližování se stálému stavu (shodnému pro všechny ekonomiky), jenž je ovlivněn řadou charakteristik a parametrů dané ekonomiky (úspory, růst populace, míra opotřebení používaných kapitálových statků, atd.).

Tato koncepce byla testována a potvrdila se pro relativně vyspělé země světa, např. studie Williamsona z roku 1965, viz (Bradley, Petrakos, Traistaru, 2005). V ostatních případech však selhávala. Moderní teorie jsou spojené s důrazem na podobu kapitálu v širokém pojetí (lidský kapitál, veřejný kapitál, technologie), což způsobuje neklesající, resp. rostoucí výnosy z používaného kapitálu. Výsledkem je nejen možnost pokračování rozdílů v ekonomické úrovni (tj. konvergence a divergence), ale i prohlubování rozdílů mezi zeměmi se shodnou úrovní, díky existenci „prríhodné kombinace“ různých faktorů. Vznikají moderní koncepty teorie endogenního rưstu, které rozšiřují koncept neoklasického kapitálu (rozšíření o lidský kapitál, veřejný kapitál, viz (Barro, Sala-i-Martin, 2004)), přikládají význam řadě dalších faktorů doposud opomíjených, jako je vzdělání populace, kvalita institucionálního prostředí apod. Na základě těchto odlišných vybavení jednotlivých ekonomik neexistuje jeden stálý stav pro jinak shodné ekonomiky (mezní produkt široce pojatého kapitálu nevykazuje klesající výnosy). Tyto modely jsou schopné teoreticky popsat empirií doložený vývoj ekonomik s vyšší mezerou v ekonomické úrovni, které rostou rychleji než jiné (ale též mohou některé země růst rychleji než ostatní i přes dosaženou vyšší ekonomickou úroveň), naopak jiné mohou stále zaostávat.

V empirickém testování se jedná zejména o rozmanité modely tzv. podmíněné a nepodmíněné konvergence, např. $\beta$-konvergence (země s nižší relativní úrovní rostou rychleji než země vyspělejší), $\sigma$-konvergence (informuje o průběhu konvergence v čase), které jsou předmětem následující podkapitoly. $\mathrm{V}$ případě tranzitivních ekonomik se $\mathrm{k}$ těmto problémům ještě připojují obtíže s transformačními a strukturálními změnami, nedostatečným pokrytím území 
statistickými šetřeními, specifickými externími vlivy apod. Proto je nutné závěry většiny těchto studií brát s ,,velkou rezervou“, spíše jako indikativní faktor než jako seriózní stavební kámen.

\subsection{Nepodmíněná vs. podmíněná konvergence}

Nepodmíněná (absolutní) konvergence vyplývající z neoklasického modelu růstu znamená, že země s nižší úrovní reálného HDP per capita vykazují vyšší tempa růstu, aniž by toto bylo podmíněno jinými charakteristikami daných ekonomik. Tento závěr plyne z vyšších temp přibližování se ke stejnému stálému stavu pro ekonomiky, jež jsou od něj dále. V úplně jednoduchém modelu, kde technologie je konstanta (např. pro Cobbovu-Douglasovu produkční funkci $Y(t)=K(t)^{\alpha} \cdot\left(A(t) \cdot L(t)^{1-\alpha}\right)$, je růst důchodu na hlavu ve stálém stavu nulový a při úrovni důchodu pod tímto stálým stavem kladný, respektive záporný pro úrovně důchodu vyšší, než odpovídá stálému stavu. V rámci nepodmíněné konvergence vždy platí, že míra přibližování se stálému stavu je rostoucí funkcí rozdílu výstupu a výstupu ve stálém stavu (Slavík, 2005, s. 7).

V konceptu podmíněné konvergence je opuštěn předpoklad shodných stálých stavů pro různé ekonomiky. Protože některé ekonomiky rostou tím rychleji, čím větší je rozdíl mezi výstupem ve stálém stavu a sledovaným výstupem, je možno nalézt i případy, kdy země s vyšší úrovní důchodu na hlavu rostou rychleji než země s nižší úrovní důchodu na hlavu, což by znamenalo, že země se ve svém bohatství od sebe vzdalují, respektive divergují. K tomuto jevu by došlo právě v případě, kdy by se země s vyšší úrovní důchodu nacházela dále od stálého stavu než země s nižší úrovní důchodu. Konvergence je pak podmíněna řadou dalších vysvětlujících proměnných, které způsobují rozdílné stavy, jako např. míra úspor, parametry účinnosti faktorů produkční funkce, vládní politiky ovlivňující polohu produkční funkce přes proměnnou $A$ zahrnující vliv technologie (zpružnění pracovního trhu, odstranění bariér obchodu, zvýšení vzdělanosti, infrastruktura) apod.

\section{$1.3 \beta$ - konvergence}

Koncept $\beta$-konvergence je definován jako situace, kdy chudší země (tedy země s nižším reálným důchodem na hlavu) rostou rychleji než země bohatší. V neoklasických modelech se však konvergencí rozumí konvergence dané ekonomiky k jejímu stálému stavu, kterým se v nejjednodušším neoklasickém modelu růstu rozumí situace, kdy důchod na hlavu je konstantní v čase. Za jistých předpokladů (viz Barro, Sala-i-Martin, 2004) lze dokázat, že ekonomika má pouze jeden stálý stav, ke kterému konverguje bez ohledu na počáteční podmínky. Zjednodušeně lze skutečný průběh $\beta$-konvergence za období $T$ kvantifikovat pomocí následující regresní rovnice:

$$
y_{i, T}-y_{i, 0}=\alpha_{1}-\beta_{1} \cdot y_{i, 0}+\varepsilon_{i}
$$

kde $i$ označuje pořadové číslo pozorování (zemi, region), $O$ a $T$ dva časové okamžiky. $\beta$ konvergence předpokládá kladnou hodnotu parametru $\beta_{1}$ a za použití dané regresní rovnice lze analyzovat, jak systematicky se v průběhu let $t=0,1,2, \ldots . T$ dařilo konvergence dosahovat. Mají-li dále všechny země stejný stálý stav $\alpha_{1}$ a časový úsek je natolik dlouhý, aby země mohly k tomuto stálému stavu konvergovat, bude $\beta_{1}=1$ a skutečně dosažený důchod na hlavu v čase $T$ shodný ve všech sledovaných zemích, k čemuž by ale došlo jen v ideálním př́ípadě. Testovaná realita je z tohoto pohledu mnohem méně uspokojivá. Regresní koeficient $\beta_{1}$ pak vlastně vyjadřuje, jak velkou část rozdílu ke stálému stavu se zemím „,v průměru“ 
podařilo skutečně eliminovat. Tento zápis dále předpokládá stálý stav s nulovým růstem na hlavu.

$\beta$-konvergenci lze také odvodit z následující regresní rovnice:

$$
\frac{1}{T} \cdot \log \left(\frac{y_{i, T}}{y_{i, 0}}\right)=\alpha_{2}-\beta_{2} \cdot \log y_{i, 0}+\varepsilon_{i}
$$

kde levá strana vyjadřuje průměrný růst v období $O$ až $T$ ( $T$ je tedy zároveň počet období). Tento růst je opět závislý (prostřednictvím koeficientu $\beta_{2}$ ) na počáteční úrovni důchodu $\left(y_{i, 0}\right)$. Teoretické odvození regresní rovnice (1.4) vychází z neoklasického modelu růstu a jedná se o vymezení pomocí regresních rovnic vyjadřujících přibližování se stálému stavu. Rovnice a odpovídající diskuse je možné nalézt v pracích (Barro, Sala-i-Martin, 1995 (kapitola 2 a 11)) či např. (Slavík, 2005, s. 8).

$\mathrm{V}$ rámci empirického zkoumání $\beta$-konvergence je možné se setkat také s modifikovaným zápisem rovnice (1.4), a to $\mathrm{v}$ podobě rovnice (1.5):

$$
\frac{1}{T} \cdot \log \left(\frac{y_{i, T}}{y_{i, 0}}\right)=\alpha+\beta \cdot \log y_{i 0}+\varepsilon_{i}
$$

kde levá strana rovnice vyjadřuje průměrný růst (HDP) ve stálých cenách v PPP v období 0 až $T$, který je závislý na počáteční ekonomické úrovni $\left(y_{i, 0}\right)$. $T$ je celkový počet let zkoumaného období, $\alpha$ úrovňová konstanta, $\beta$ je regresní koeficient a $\varepsilon_{i}$ je náhodná složka. $\mathrm{K} \beta$ konvergenci dochází při záporné směrnici přímky beta. $V$ opačném případě, při kladné směrnici přímky beta, dochází $\mathrm{k}$ divergenci. Čím je v absolutní hodnotě koeficient $\beta$ větší, tím rychlejší je konvergence. Na tomto místě je vhodné zdůraznit, že výše uvedená rovnice, která byla použita pro empirické srovnání např. v práci (Slavík, 2007), implicitně předpokládá shodné stálé stavy ve sledovaných ekonomikách. Prokáže-li se $\beta$-konvergence za pomoci této rovnice, prokáže se zároveň absolutní konvergence, protože tato rovnice nezahrnuje možnou existenci různých stálých stavů (zahrnutím dalších proměnných jako např. institucionálního rámce, zahraničního obchodu, jazykové vybavenosti obyvatelstva či jiných proměnných $\mathrm{v}$ rámci podmíněné konvergence, jež jsou uvedeny v podkapitole 1.2).

\section{$1.4 \sigma$-konvergence}

Koncept $\sigma$-konvergence vychází rovněž z neoklasického modelu růstu, na základě kterého všechny státy konvergují ke stejné úrovni vyspělosti anebo ke stejnému ekonomickému výkonu. Je definována jako snižování variance logaritmu reálného HDP na obyvatele mezi ekonomikami včase. Pokud označíme varianci logaritmu reálného HDP na obyvatele ve skupině zemí v čase $t$, potom tedy $\sigma$-konvergence v období mezi $t$ a $t+1$ znamená:

$$
\sigma_{t}>\sigma_{t+1}
$$

Ex post můžeme zápis (1.6) formulovat následujícím způsobem:

$$
\sigma_{t-1}>\sigma_{t}
$$

Pokud bychom zkoumali vztah mezi $\sigma$-konvergencí a definicí konvergence uvedenou v kapitole 1.1, zjistíme, že nerovnice (1.7) a tedy i nerovnice (1.6) odpovídá definici konvergence, jež je uvedena ve formalizovaném zápisu nerovnice (1.1). Na tomto místě je 
ovšem důležité zmínit, jakým způsobem je analyzována daná veličina. Bud’ může být chápána jako stochastická náhodná veličina sledující nějaký proces a cílem analýzy je tento proces postihnout, nebo je předmětem zájmu pouze výsledný efekt konvergence (nerovnice 1.7). Kritérium $\sigma$-konvergence bylo sestrojeno za účelem získání dodatečných informací o cestě konvergence, které přístup $\beta$-konvergence neumožňuje. Původně byl tento přístup definován pro reálný důchod, s jeho pomocí lze však zkoumat i jiné ekonomické veličiny.

Za předpokladu obvyklé definice pomocí relativních odstupů, např. (Smrčková, Vlček, Cvengroš, 2008), jsou $\beta$-konvergence a $\sigma$-konvergence ekvivalentní, což znamená, že při rychlejším růstu zemí s nižší počáteční úrovní se v čase snižuje variační koeficient tohoto vzorku zemí. Při definici na absolutních diferencích, např. (Slavík, 2007), je existence $\beta$ konvergence nutnou podmínkou pro $\sigma$-konvergenci, přičemž opačně tento vztah platit nemusí. Jestliže existuje velký rozdíl počátečních úrovní, pak při nevelkém růstovém diferenciálu se může absolutní odstup těchto ekonomik zvětšovat. Je však nutno si uvědomit, že oba indikátory popisují konvergenci jako převažující proces sbližování ekonomických úrovní. To znamená, že i v případě, kdy obecně dochází ke konvergenci, mohou existovat ekonomiky, které divergují.

\section{Empirická analýza reálné $\beta$-konvergence regionů zemí Visegrádské čtyřky}

\subsection{Metodologická východiska a specifikace ekonometrického přístupu}

Pro hodnocení úrovně konvergenčního procesu v regionech V4 vycházíme z platného neoklasického modelu růstu, kde růst $\mathrm{HDP}$ je negativně závislý na počáteční ekonomické úrovni a ekonomika konverguje ke svému stálému stavu. Při formulaci ekonometrického modelu vycházíme z konceptu $\beta$-konvergence (viz podkapitolu 1.3), jenž je aplikován při hodnocení vývoje zemí (tj. v pojetí nomenklatury územních statistických jednotek EU úroveň NUTS 0 či NUTS 1), a tento koncept analogicky použijeme pro úroveň nižších územních jednotek - regionů NUTS 2. Pro účely odhadu regresního modelu bude využit koncept regresní rovnice pro testování $\beta$-konvergence, který byl navržen v práci autorů Barro, Sala-iMartin (2004) a využit také v pracích výše zmiňovaných českých autorů, např. (Slavík, 2005, 2007). První přístup reprezentuje ekonometrický model, který je založen na nelineárním regresním modelu a je odhadnut klasickou metodou nejmenších čtverců. Pro účely tohoto článku však vycházíme $\mathrm{z}$ určité modifikace tradičního postupu, a to především díky těmto argumentům:

1. Rovnice (1.5) předpokládá měření velikosti rozdílu konvergence daného regionu (země) ke stálému stavu při tzv. nulovém růstu. Tento nulový růst náš př́ístup nepředpokládá a naopak prezentuje výsledky při zohlednění vývoje HDP v celém sledovaném období. Uvedený postup považujeme za logický a věcně správný.

2. Neprovádíme výzkum skupin zemí a jejich vývoje ke stálému stavu, ale naopak sledujeme vývoj každého z 35 posuzovaných regionů NUTS 2.

K $\beta$-konvergenci pak bude docházet při kladné směrnici přímky $\beta_{r, t}$. V opačném př́ípadě, při záporném znaménku směrnice $\beta_{r, t}$, bude docházet $\mathbf{k}$ divergenci. Toto bude platit při respektování pravidel statistické signifikace. Při hodnocení toho, zda region konverguje, respektujeme dvě základní skutečnosti: 
a. kladná směrnice přímky je způsobena konvergencí regionů zdola směrem k průměrné úrovni;

b. při dosazení do vzorce (2.1) můžeme získat zápornou hodnotu na levé straně rovnice, pokud je průměr vyšší než výkonnost regionu NUTS 2.

Ekonometrický model budeme modifikovat, dle výše uvedených argumentů, přičemž vycházíme $\mathrm{z}$ obecné formulace rovnice (1.5) pro měření $\beta$-konvergence. Následující modifikovaná rovnice má tvar (2.1):

$$
\log \left(\frac{y_{r, t}}{y_{E U, t}}\right)=\hat{\alpha}_{r, t}+\hat{\beta}_{r, t} \log y_{E U, t}+\hat{\varepsilon}_{r, t}
$$

kde: $\quad y_{r, t} \quad$ HDP na obyvatele za daný r-tý region NUTS 2;

$y_{E U, t}$ průměrná úroveň HDP na obyvatele za všechny regiony EU15 v daném roce;

$\alpha_{r, t} \quad$ úrovňová konstanta;

$\beta_{r, t} \quad$ parametr sklonu regresního modelu;

$t \quad$ referenční období let 1995 - 2006;

$\varepsilon_{r, t} \quad$ náhodná složka.

Pojd’me se nyní blíže podívat na podstatu samotného modelu. V případě, že chceme hodnotit úroveň konvergence, případně divergence regionů zemí $\mathrm{V} 4$, musíme si stanovit, co je tzv. stálým stavem, tedy úrovní rychlosti konvergence k vymezenému stálému stavu. Stálým stavem určíme hodnotu ekonomické úrovně vyspělých zemí EU15. Můžeme předpokládat, že se v čase bude zvyšovat, případně snižovat úroveň výkonnosti hodnocených regionů zemí V4, avšak budeme předpokládat hypotézu, že se $\mathbf{v}$ jednotlivých letech celková výkonnost regionů zvyšovala, a při stávající dostupnosti dat budeme pracovat s vypočteným průměrem za regiony EU15. Tento průměr a jeho vývoj v čase budeme chápat jako úroveň pro výchozí hodnocení reálné konvergence. Proto také porovnáváme, jak se jednotlivé regiony NUTS 2 zemí V4 v průřezu let 1995 - 2006 prribližovaly svou ekonomickou výkonností ke stálému stavu, tj. průměru EU15. Přitom musíme upřesnit, že průměr za EU15 byl dopočítán pro každý rok z referenčního období samostatně.

Druhý přístup zase řeší problematiku konvergenčního procesu, kdy změna HDP EU15 je determinována změnou HDP příslušného regionu NUTS 2 aplikací nelineárního regresního modelu s využitím techniky umělých proměnných pro regiony NUTS 2 zemí Visegrádské čtyřky. Cílem tohoto př́istupu je ukázat, jak rychle regiony NUTS 2 konvergují ke stálému stavu v referenčním období 1995 - 2006.

Formalizovaný zápis modelu v rámci druhého přístupu má tento tvar:

$$
\ln y_{E U, t}=\hat{\alpha}+\hat{\beta} \ln x_{r, t}+\sum_{r=1}^{35} \hat{\gamma}_{r} D_{r, t}+\hat{\varepsilon}_{r, t}
$$


kde:

$y_{E U, t}$ endogenní proměnná (HDP na obyvatele za EU15 v průměru);

$x_{r, t} \quad$ exogenní proměnná (HDP na obyvatele za region NUTS 2);

$\alpha \quad$ úrovňová konstanta;

$\beta \quad$ parametr sklonu regresního modelu;

$\gamma_{r} \quad$ rozdílový parametr fixního efektu úrovňové konstanty regionu;

$\varepsilon_{r, t} \quad$ náhodná složka;

$D_{r, t} \quad$ binární proměnná pro specifikaci regionů (úroveň regionálního HDP na obyv.);

$D_{r, t}=1$ jestliže se jedná o data regionu ,,$r^{\prime “} \mathrm{v}$ čase $, t t^{*},\left(D_{r, t}=0\right.$ jinak $) ;$

$r \quad$ indexuje průřezovou charakteristiku - v našem případě regiony $\mathrm{V} 4$;

$r \quad$ regiony NUTS 2 (základním „,regionem“ je průměr EU 15),

$r=1,2, \ldots, 35$ (v našem případě 35 regionů Visegrádské čtyřky);

$t \quad$ indexuje čas; $t=1995,1996, \ldots, 2006$.

Z legendy rovnice regresního lineárního modelu panelových dat (2.2) vyplývá, že je nutné, dříve než bude proveden odhad modelu, prriřadit umělé proměnné $D_{r, t}$ pro jednotlivé regiony NUTS 2 Visegrádské čtyřky. Celkově tedy model bude obsahovat 35 těchto umělých proměnných, jejichž přiřazení je patrné z následující tabulky 2.1 . 
Tab. 2.1 - Přiřazení umělých proměnných pro jednotlivé regiony NUTS 2

\begin{tabular}{|c|c|c|}
\hline $\begin{array}{c}\text { Umělá } \\
\text { proměnná }\end{array}$ & $\begin{array}{c}\text { Kód } \\
\text { regionu }\end{array}$ & Název regionu \\
\hline$D_{1 t}$ & CZ01 & Praha \\
\hline$\overline{D_{2 t}}$ & $\mathrm{CZO2}$ & Střední Čechy \\
\hline$D_{3 t}$ & CZ03 & Jihozápad \\
\hline$D_{4 t}$ & CZ04 & Severozápad \\
\hline$D_{5 t}$ & $\mathrm{CZ05}$ & Severovýchod \\
\hline$D_{6 t}$ & CZ06 & Jihovýchod \\
\hline$D_{7 t}$ & CZ07 & Střední Morava \\
\hline$D_{8 t}$ & CZ08 & Moravskoslezsko \\
\hline$D_{9 t}$ & HU10 & Středomad'arský region \\
\hline$D_{10 t}$ & HU21 & Středozadunajský region \\
\hline$D_{11 t}$ & HU22 & Západozadunajský region \\
\hline$D_{12 t}$ & HU23 & Jihozadunajský region \\
\hline$D_{13 t}$ & HU31 & Severomad'arský region \\
\hline$D_{14 t}$ & HU32 & Severní Velká Planina \\
\hline$D_{15 t}$ & HU33 & Jižní Velká Planina \\
\hline$D_{16 t}$ & PL11 & Lódzkie \\
\hline$D_{17 t}$ & PL12 & Mazowieckie \\
\hline
\end{tabular}

\begin{tabular}{|c|c|c|}
\hline$D_{18 t}$ & PL21 & Malopolskie \\
\hline$D_{19 t}$ & PL22 & Slaskie \\
\hline$D_{20 t}$ & PL31 & Lubelskie \\
\hline$D_{21 t}$ & PL32 & Podkarpackie \\
\hline$D_{22 t}$ & PL33 & Swietokrzyskie \\
\hline$D_{23 t}$ & PL34 & Podlaskie \\
\hline$D_{24 t}$ & PL41 & Wielkopolskie \\
\hline$D_{25 t}$ & PL42 & Zachodniopomorskie \\
\hline$D_{26 t}$ & PL43 & Lubuskie \\
\hline$D_{27 t}$ & PL51 & Dolnoslaskie \\
\hline$D_{28 t}$ & PL52 & Opolskie \\
\hline$D_{29 t}$ & PL61 & Kujawsko-Pomorskie \\
\hline$D_{30 t}$ & PL62 & Warminsko-Mazurskie \\
\hline$D_{31 t}$ & PL63 & Pomorskie \\
\hline$D_{32 t}$ & SK01 & Bratislavský kraj \\
\hline$D_{33 t}$ & SK02 & Západní Slovensko \\
\hline$D_{34 t}$ & SK03 & Střední Slovensko \\
\hline$D_{35 t}$ & SK04 & Východní Slovensko \\
\hline & Zdroj: Eurostat, 2010; vlastní zpracování \\
\hline
\end{tabular}

Datová základna modelu pro měření reálné konvergence v regionech V4 je tvořena regionálními daty HDP na obyvatele ve stálých cenách, jež jsou k dispozici v databázi Organizace pro hospodáŕskou spolupráci a rozvoj (OECD, 2010). Srovnatelnost dat v čase je zajištěna jejich přepočítáním na USD ve stálých cenách roku 2000 podle parity kupní síly (PPP) metodou EKS (Elteto-Koves-Szulc), která je pro mezinárodní komparace využívána jak OECD, tak Eurostatem. Porovnávání pomocí užití stálých cen a stálé parity určitého zvoleného roku přesně replikuje dynamiku HDP a populace a na druhé straně abstrahuje od změn směnných relací a struktury. Předmětem analýzy je 35 regionů NUTS 2 zemí V4 v referenčním období 1995 - 2006, kdy při využití ročních dat pracujeme jen s malým vzorkem pozorování. Problému omezené délky časové řady ročního regionálního HDP na obyvatele, jenž do jisté míry může ovlivňovat výsledky analýzy, jsme si vědomi. Na druhou stranu však nepovažujeme za smysluplné pro tranzitivní ekonomiky zkoumat data např. před rokem 1995, kdy nebyla využívána jednotná metodika měření HDP v rámci systému ESA 95. Vhodným řešením z hlediska počtu pozorování by bylo využití regionálních dat se čtvrtletní periodicitou, čímž by byl zajištěn dostatečně reprezentativní vzorek pozorování. Nicméně čtvrtletní regionální data reálného HDP na obyvatele v PPP nebyla ve zkoumané databázi OECD (http://stats.oecd.org) či databázi Eurostatu (http://epp.eurostat.ec.europa.eu) veřejně dostupná. Ani řešení v podobě prodloužení časové řady regionálního HDP na obyvatele o novější údaje není vhodné z důvodu chybějícího sezónního očištění těchto dat. V panelovém modelu, využitém při druhém př́istupu, umíme koncentrovat více informací než v jednoduchém klasickém regresním modelu. Jsme schopni 
lépe postihnout dynamiku změny, k níž u jednotlivých proměnných došlo. Zásadní výhodou je detekce fixních, resp. stochastických efektů, které bychom nebyli schopni diagnostikovat aplikací pouze prưřezových dat anebo časové řady. Další výhodou je konstrukce a testování složitějších modelů s odpovídajícím počtem stupňů volnosti. Jiné výhody a nevýhody makroekonometrického modelování uvádí např. Šmídková (2005). Při aplikaci modelu panelových dat jsou rovněž značně eliminovány odchylky způsobené agregací užitých datových soubori̊.

\subsection{Odhad ekonometrického modelu}

Pro potřeby výpočtu bude využit software SPSS for Windows (verze 15.0). Jestliže máme k dispozici regionální roční data HDP na obyvatele za regiony V4 v referenčním období let 1995 - 2006, vznikne nám v prvním případě celkem 35 regresních rovnic, v rámci kterých můžeme posoudit, jak se konkrétní regiony NUTS 2 zemí V4 (35 regionů) postupně přibližovaly, případně vzdalovaly průměrné úrovni EU. Odhad parametru $\beta_{r, t}$ proto bude pro další hodnocení úrovně konvergenčního procesu regionů klíčový. Bude nám totiž ukazovat, které regiony se přibližují ke stálému stavu a které se od něj vzdalují, př́ípadně situaci, kdy nemůžeme o procesu konvergence či divergence jednoznačně rozhodnout. Druhý přístup potom ukazuje pořadí regionů $\mathrm{z}$ hlediska rychlosti jejich konvergence $\mathrm{k}$ průměrné úrovni zemí EU15. V tomto případě zase sledujeme vývoj parametru $\gamma_{r}$. Výsledný odhad zaznamenává rovnice (2.3):

$$
\ln H \hat{D} P_{E U, t}=6,642+0,41 \ln H D P_{r, t}-0,757 D_{1, t}+\ldots+\left(-0,037 D_{34, t}\right)
$$

Výstupy obou přístupů shrnuje tabulka 2.2 pro všech 35 analyzovaných regionů NUTS 2 zemí Visegrádské čtyřky.

\subsection{Interpretace výsledků}

Při propočtu odhadu regresních modelů v jednotlivých obdobích vzniklo celkem 35 regresních parametrů hodnotících $\beta$-konvergenci. Výsledky jsou uvedeny v tabulce 2.2. Konkrétně nás bude $\mathrm{v}$ obou modelech zajímat hodnota parametru $\beta$, protože jestliže bude tento parametr (koeficient) kladný, můžeme říci, že dochází $\mathrm{k} \beta$-konvergenci, v př́ipadě záporné hodnoty potom $\mathrm{k} \beta$-divergenci (v našem případě se regionální divergence vůbec nepotvrdila).

První prrístup identifikoval u některých regionů $\beta$-konvergenci, eventuelně, v případě statistické nevýznamnosti parametru $\beta_{r, t}$, nejednoznačný závěr o konvergenci, př́padně divergenci daného regionu NUTS 2 vůči EU15. Proto také zohledňujeme statistickou významnost a součástí každého odhadu tudíž byla statistická verifikace a ekonometrická verifikace (s ohledem na omezený rozsah článku zde výsledky ekonometrické verifikace neuvádíme). Pro testování statistické významnosti modelu jako celku byl použit tzv. F-test a pro testování dílčích regresních koeficientů je užíván tzv. t-test. Musíme konstatovat, že v drtivé většině odhadů vycházely odhady regresních koeficientů jako statisticky významné na zvolené 5\% hladině významnosti (viz sloupec „p-hodnota“). To znamená, že můžeme objektivně zhodnotit, na základě uvedené formulace modelu (2.1), zda ke konvergenci v regionech zemí V4 dochází, či nikoliv. O relevanci výsledků svědčí také poměrně vysoká hodnota koeficientu determinace $\left(\mathrm{R}^{2}\right)$.

Shrneme-li výsledky prvního př́istupu, potom lze konstatovat, že v rámci V4 existuje skupina regionů, která prokazatelně konverguje $\mathrm{k}$ průměrné úrovni, která se v čase logicky mění. Mezi tyto regiony patří regiony Polska a Mad'arska. Vedle toho detekujeme skupinu regionů, u které nemůžeme rozhodnout o $\beta$-konvergenci či $\beta$-divergenci z důvodu statistické nevýznamnosti 
u parametru $\beta_{r, t}$. Zde řadíme všechny regiony Slovenska a 6 regionů České republiky s relativně nízkou ekonomickou výkonností.

Po provedení odhadu v rámci druhého přístupu bylo zvoleno u parametru $\gamma_{r}$ následující pravidlo: Čím je hodnota koeficientu $\gamma_{r}$ v absolutní hodnotě větší, tím vzdálenější je daný region od průměru EU, který je reprezentován hodnotou úrovňové konstanty (tento region by tudíž měl konvergovat pomaleji $k$ úrovni EU za sledované období). Tabulka 2.2 tedy ukazuje pořadí regionů $\mathrm{V} 4 \mathrm{v}$ rámci rychlosti konvergence vůči stálému stavu (viz sloupec „pořadí z hlediska rychlosti konvergence“). Druhý přístup v zásadě nezohledňuje, zda region konverguje nebo diverguje, ale preferujeme zde obecnou tezi o tom, že všechny regiony konvergují směrem k průměrné úrovni, ale každý jinou rychlostí. Proto jsme vzali v potaz hodnoty parametru $\gamma_{r}$, které byly seřazeny pomocí MS Excel a podle dosaženého pořadí bylo určeno výsledné pořadí dle rychlosti konvergence. $V$ rámci pořadí zcela vypadnul region SKO4 (Východní Slovensko), nebot' při porovnání ekonomické úrovně vůči průměru EU byl $\mathrm{z}$ modelu vyloučen $\mathrm{z}$ důvodu statistické nevýznamnosti parametru $\gamma_{35}$. Výsledné pořadí odpovídá představě o konvergenčních předpokladech jednotlivých regionů $\mathrm{v}$ rámci geografického prostoru EU. 
Tab. 2.2: Odhad ekonometrického modelu $\beta$-konvergence pro regiony NUTS 2 zemí V4 v letech 1995 - 2006 k průměru EU15

\begin{tabular}{|c|c|c|c|c|c|c|c|}
\hline \multirow{2}{*}{$\begin{array}{c}\text { Model } \\
\text { Regresní } \\
\text { rovnice }\end{array}$} & \multicolumn{2}{|r|}{ Region } & \multirow{2}{*}{$\begin{array}{c}\begin{array}{c}\text { Parametr } \\
\text { sklonu }\end{array} \\
\left(\beta_{1}\right)\end{array}$} & \multirow{2}{*}{ p-hodnota } & \multirow{2}{*}{$\begin{array}{c}\mathbf{R}^{2} \\
(\%)\end{array}$} & \multirow[b]{2}{*}{ Závěr } & \multirow{2}{*}{$\begin{array}{c}\text { Pořadí } \\
\text { z hlediska } \\
\text { rychlosti } \\
\text { konvergence }\end{array}$} \\
\hline & Kód & Název & & & & & \\
\hline 1 & CZ01 & Praha & 1,457 & 0,000 & 91,4 & $\beta$-konvergence & 1. \\
\hline 2 & $\mathrm{CZO2}$ & Střední Čechy & 0,819 & 0,000 & 74,1 & $\beta$-konvergence & 5. \\
\hline 3 & CZ03 & Jihozápad & 0,097 & 0,700 & 1,5 & nejednoznačný & 4. \\
\hline 4 & $\mathrm{CZO4}$ & Severozápad & $-0,538$ & 0,090 & 26,0 & nejednoznačný & 10. \\
\hline 5 & CZ05 & Severovýchod & $-0,085$ & 0,634 & 2,4 & nejednoznačný & 8. \\
\hline 6 & $\mathrm{CZ06}$ & Jihovýchod & 0,186 & 0,436 & 6,2 & nejednoznačný & 7. \\
\hline 7 & $\mathrm{CZ07}$ & Střední Morava & $-0,217$ & 0,345 & 8,9 & nejednoznačný & 12. \\
\hline 8 & CZ08 & Moravskoslezsko & $-0,101$ & 0,805 & 0,6 & nejednoznačný & 11. \\
\hline 9 & HU10 & Středomad’arský region & 2,023 & 0,000 & 94,0 & $\beta$-konvergence & 2. \\
\hline 10 & HU21 & $\begin{array}{l}\text { Středozadunajský } \\
\text { region }\end{array}$ & 1,407 & 0,000 & 89,4 & $\beta$-konvergence & 13. \\
\hline 11 & HU22 & $\begin{array}{l}\text { Západozadunajský } \\
\text { region }\end{array}$ & 1,329 & 0,000 & 91,4 & $\beta$-konvergence & 9. \\
\hline 12 & HU23 & Jihozadunajský region & 0,720 & 0,000 & 83,1 & $\beta$-konvergence & 22. \\
\hline 13 & HU31 & Severomad'arský region & 1,053 & 0,001 & 69,4 & $\beta$-konvergence & 27. \\
\hline 14 & HU32 & Severní Velká Planina & 1,014 & 0,001 & 71,6 & $\beta$-konvergence & 26. \\
\hline 15 & HU33 & Jižní Velká Planina & 0,512 & 0,006 & 54,4 & $\beta$-konvergence & 23. \\
\hline 16 & PL11 & Lódzkie & 1,329 & 0,000 & 93,5 & $\beta$-konvergence & 21. \\
\hline 17 & PL12 & Mazowieckie & 1,952 & 0,000 & 92,6 & $\beta$-konvergence & 3. \\
\hline 18 & PL21 & Malopolskie & 0,928 & 0,000 & 79,5 & $\beta$-konvergence & 24. \\
\hline 19 & PL22 & Slaskie & 0,718 & 0,001 & 66,2 & $\beta$-konvergence & 14. \\
\hline 20 & PL31 & Lubelskie & 0,422 & 0,005 & 56,2 & $\beta$-konvergence & 31. \\
\hline 21 & PL32 & Podkarpackie & 0,544 & 0,003 & 60,1 & $\beta$-konvergence & 32. \\
\hline 22 & PL33 & Swietokrzyskie & 1,031 & 0,000 & 91,4 & $\beta$-konvergence & 29. \\
\hline 23 & PL34 & Podlaskie & 0,828 & 0,000 & 81,3 & $\beta$-konvergence & 30. \\
\hline 24 & PL41 & Wielkopolskie & 1,388 & 0,000 & 89,7 & $\beta$-konvergence & 15. \\
\hline 25 & PL42 & Zachodniopomorskie & 0,573 & 0,000 & 88,7 & $\beta$-konvergence & 18. \\
\hline 26 & PL43 & Lubuskie & 0,733 & 0,001 & 68,4 & $\beta$-konvergence & 20. \\
\hline 27 & PL51 & Dolnoslaskie & 1,045 & 0,000 & 80,8 & $\beta$-konvergence & 16. \\
\hline 28 & PL52 & Opolskie & 0,267 & 0,219 & 14,7 & nejednoznačný & 25. \\
\hline 29 & PL61 & Kujawsko-Pomorskie & 0,694 & 0,000 & 83,9 & $\beta$-konvergence & 19. \\
\hline 30 & PL62 & $\begin{array}{l}\text { Warminsko- } \\
\text { Mazurskie }\end{array}$ & 0,840 & 0,000 & 77,3 & $\beta$-konvergence & 28. \\
\hline 31 & PL63 & Pomorskie & 0,998 & 0,000 & 89,4 & $\beta$-konvergence & 17. \\
\hline 32 & SK01 & Bratislavský kraj & 1,213 & 0,158 & 18,9 & nejednoznačný & 6. \\
\hline 33 & SK02 & Západní Slovensko & 0,695 & 0,393 & 7,4 & nejednoznačný & 33. \\
\hline 34 & SK03 & Střední Slovensko & 0,492 & 0,463 & 5,5 & nejednoznačný & 34. \\
\hline 35 & SK04 & Východní Slovensko & 0,371 & 0,575 & 3,2 & nejednoznačný & N/A \\
\hline
\end{tabular}

Zdroj: Vlastní výpočty a úpravy autorů na základě dat OECD (http://stats.oecd.org/Index.aspx), 2010 


\section{Závěr}

Prezentované výsledky jsou modifikací tradičních přístupů. Důvody, které nás vedly k těmto úpravám, byly popsány výše. Uvedené ekonometrické modely regionální konvergence ukazují, že koncept hodnocení úrovně konvergenčního procesu je přímo závislý na tom, jak je definován stálý stav, nebot' to jednoznačně ovlivňuje dosažené výsledky. Důkazem toho jsou výsledky dřívějších prací (Melecký, 2010), (Melecký, Nevima, 2010), kde byla rovněž provedena analýza reálné konvergence pomocí konceptu $\beta$-konvergence pro regiony NUTS 2 zemí V4 za stejné referenční období. Rozdíl však spočíval v definici stálého stavu a formátu zadávací datové tabulky pro odhad ekonometrického modelu. Zatímco v tomto článku jsme se pokoušeli o analýzu reálné konvergence postupně u všech regionů NUTS 2 (35 regresních rovnic) ve stejném referenčním intervalu ke stálému stavu, tj. průměrné hodnotě EU15 v období 1995 - 2006, starší práce zahrnovaly 11 regresních rovnic, v rámci kterých bylo možné posoudit, jak se regiony NUTS 2 zemí V4 postupně přibližovaly/vzdalovaly v referenčním období 1995 - 2006 jako celek od stálého stavu. Šlo tedy o zkoumání toho, jak regiony celkově konvergovaly ke stálému stavu, tj. ekonomické úrovni, kterou regiony zemí V4 dosáhly v posledním sledovaném roce 2006.

Z výsledků dřívějších prácí vyplynuly, na rozdíl od tohoto příspěvku, daleko méně jednoznačné závěry, nebot' reálná konvergence byla potvrzena pouze ve dvou z jedenácti sledovaných časových úseků. V tomto příspěvku však výsledky působí zcela jednoznačně a hypotéza konvergenčního procesu reálné $\beta$-konvergence byla potvrzena, obdobně jako v dřivější práci (Melecký, Nevima, 2010b). Musíme však zdůraznit, že uvedené výsledky jsou založeny na tzv. nepodmíněné $\beta$-konvergenci, protože jinak by v regresní rovnici musely být zahrnuty další proměnné, například institucionální rámec, vývoj zahraničního obchodu, jazyková gramotnost obyvatel atd. Tímto rozšírením bychom potom analyzovali tzv. podmíněnou $\beta$-konvergenci. To by však znamenalo zcela jinou specifikaci modelu, rovněž tato data nejsou za jednotlivé regiony dostupná. Druhý použitý přístup podpořil teorii reálné konvergence aplikací nelineárního regresního modelu s využitím techniky umělých proměnných, pomocí kterého se nám podařilo posoudit rychlost konvergence jednotlivých regionů jejím porovnáním s průměrnou úrovní HDP na obyvatele EU15. V tomto kontextu došlo k seřazení hodnot a určení pořadí regionů podle rychlosti jejich konvergence k průměrné úrovni. Výsledky lze samozřejmě podrobit kritické analýze, ale článek ukázal možnosti, jakým způsobem můžeme stále dosti nejednoznačný koncept konvergence hodnotit.

V rámci dalšího zkoumání regionální konvergence by bylo vhodné rozšíríit datovou základnu o větší počet pozorování či zvolit alternativní hodnotu stálého stavu (např. EU27 předpokládáme zde podobné výsledky jako v případě zkoumání konvergence regionů V4 k EU15). K získání hlubších závěrů může přispět i využití konceptu $\sigma$-konvergence, ke které dochází, pokud se variační koeficient ekonomických úrovní jednotlivých zemí (regionů) $\mathrm{v}$ čase snižuje. I přes výše uvedené podněty a s vědomím toho, že za probíhající reálnou konvergencí stojí i jiné faktory než jen determinanty reálného ekonomického růstu, jsou výsledky provedené analýzy cenné a mohou nabídnout další pohled na ekonomický vývoj v regionech zemí Visegrádské čtyřky.

\section{Literatura:}

[1] BARRO, R. J., SALA-I-MARTIN, X. X. Economic Growth. First edition. New York: McGraw-Hill, 1995. ISBN 0-07-003697-7.

[2] BARRO, R. J., SALA-I-MARTIN, X. X. Economic Growth. Second edition. Cambridge: The MIT Press, 2004. 654 s. ISBN 978-0-262-02553-9. 
[3] BRADLEY, J., PETRAKOS, G. C., TRAISTARU, I. Integration, growth and cohesion in an enlarged European Union. New York, Springer 2005. (ZEI studies in European economics and law 7.), 348 s. ISBN 0-38722-853-5.

[4] DVOROKOVÁ, K. Ekonometrická analýza konvergence inflace České republiky k vybraným zemím Eurozóny. In Evropská unie po českém predsednictví. Sborník abstraktů příspěvků z mezinárodní vědecké konference pořádané u příležitosti 160 . výročí založení VŠB-TU Ostrava. [CD ROM]. Ostrava: EkF VŠB-TU Ostrava, 10. - 11. záríi 2009, s. 1 - 9. ISBN 978-80-248-2057-6.

[5] FRAIT, J., KOMÁREK, L. Na cestě do Evropské unie: nominální a reálná konvergence v tranzitivních ekonomikách. In Finance a úvěr, 2001, ročník 51, č. 6, s. 314 - 330. ISSN 0015-1920.

[6] HANČLOVÁ, J. Output convergence amongst the NUTS 2 regions of Visegrad countries. In 28th International Conference on Mathematical Methods in Economics 2010. University of South Bohemia in České Budějovice: Faculty of Economics, 2010. s. 201 -207. ISBN 978-80-7394-218-2.

[7] KUTAN, A. M., YIGIT, T. M. European integration, productivity growth and real convergence. European Economic Review, Volume 51, Issue 6, August 2007. p. 1370 1395.

[8] MAGRINI, S. Regional (di)convergence. Handbook of Regional and Urban Economics, Volume 4, 2004. p. 2741-2796.

[9] MELECKÝ, L. Analýza reálné konvergence vybraných regionů zemí EU-15 prostřednictvím ekonometrického modelu beta konvergence. In Udržitelný rozvoj $v$ evropských regionech. České Budějovice, 8. - 9. dubna 2010. České Budějovice: VŠERS, 2010. s. 1-11.

[10] MELECKÝ, L, NEVIMA, J. Aplikace přístupů ekonometrického modelování v rámci analýzy reálné konvergence regionů zemí Visegrádské čtyřky. In Hradecké ekonomické dny 2010. Hradec Králové: Univerzita Hradec Králové, 2010a, Fakulta informatiky. s. 271 - 275. ISBN 978-80-7435-040-5.

[11] MELECKÝ, L, NEVIMA, J. Analýza reálné konvergence regionů zemí Visegrádské čtyřky prostřednictvím ekonometrického modelu. In IMEA 2010. 10th International Conference of Postgraduate Students and Young Scientists. Conference Proceedings. Pardubice: Univerzita Pardubice, Fakulta ekonomicko-správní, 2010b. s. 1 - 15. ISBN 978-80-7395-254-9.

[12] MELECKÝ, L., NEVIMA, J. Regionální konkurenceschopnost a možnosti jejího hodnocení v zemích V4 prostřednictvím aplikace specifických ekonomických koeficientů. Acta academica karviniensia, Ročník 2009, č. 2, s. 247 - 264. ISSN 1212$415 \mathrm{X}$.

[13] OECD [online]. Total Economy Database - OECD. StatExtrats. Regional statistics. 2010. [cit. 24.2.2010]. Dostupný z WWW: <http://stats.oecd.org/Index.aspx>.

[14] RAMAJO, J., MÁRQUEZ, M. A., HEWINGS, G. J. D., SAliNAS, M. M., Spatial heterogenity and interregional spillovers in the European Union: Do cohesion policies encourage convergence across regions? European Economic Review, Volume 52, Issue 3, April 2008. p. $551-567$.

[15] ROMEO-AVILA, D.: The convergence hypothesis for OECD countries reconsidered: panel data evidence with multiple breaks, 1870-2003. In Manchester School 77, 2009. p. 552-574.

[16] SALA-i-MARTIN, X.X. Regional cohesion: evidence and theories of regional growth and convergence. European Economic Review, Volume 40, Issue 6, June 1996. p. 1325 -1352 . 
[17] SLAVÍK, C. Reálná konvergence České republiky $k$ EU v porovnání s ostatními novými členskými zeměmi. Praha: FSV UK, 2005. 32 s. Pražské sociálně vědní studie. Veřejná politika a prognostika, PPF-003. ISSN 1801-5999.

[18] SLAVÍK, C. Reálná konvergence České republiky k Evropské unii. In Politická ekonomie, 2007, č. 1, s. 23 - 40. ISSN 0032-3233.

[19] SMRČKOVÁ, G., VLČEK, I., CVENGROŠ, F. Reálná konvergence - souvislosti a př́činy. Výzkumná studie pro Ministerstvo financí ČR [online]. Praha: Ministerstvo financí ČR, 2008. Dostupný z WWW:

$<$ http://www.mfcr.cz/cps/rde/xbcr/mfcr/Proces_realne_konvergence_MF_2008_pdf.pdf.

[20] ŽĎÁREK, V. Konvergence nových členských zemí EU a aktuální problémy [online]. 2006. [cit. 20.2.2010]. Dostupný z WWW: <http://www.vsem.cz/data/data/cessoubory/konference-seminare/gf_Brno0906_VZ.pdf>.

Klasifikace JEL: C33, O18, R11, R15

\section{Ing. Jan Nevima, Ph.D.}

Katedra matematických metod v ekonomice

Ekonomická fakulta

VŠB - TU Ostrava

Sokolská 33, 70121 Ostrava

jan.nevima@oao.cz

\section{Ing. Lukáš Melecký}

Katedra evropské integrace

Ekonomická fakulta

VŠB - TU Ostrava

Sokolská 33, 70121 Ostrava

lukas.melecky@vsb.cz 